\title{
Seeking Philosophical Foundations for Ecological Civilization: Natural Theology East and West
}

\section{Yih-hsien Yu* \\ Department of Philosophy, Tunghai University, Taiwan}

*Corresponding author: Yih-hsien Yu, Department of Philosophy, Tunghai University,

Taichung, Taiwan, Email: arche@thu.edu.tw

\section{Review Article}

Volume 2 Issue 1

Received Date: December 10, 2019

Published Date: December 31, 2019

DOI: $10.23880 /$ abca-16000111

*This article was rewritten from my previous paper "Seeking a Philosophical Foundation for an Age of Spiritual Ecology: Natural Theology Revisited," published by UNIVERSITAS: Monthly Review of Philosophy and Culture, July 2012, Vol. 39, No. 7, Issue 458, New Taipei City, Taiwan, ROC.

\section{Abstract}

The chief purposes of the present paper are twofold. One is to maintain that underlying the breakdown of the bioecological system conducive to the increasing environmental crises threatening the sustainable existence of both mankind and nature, has been a breakdown of the psycho-ecological (or spiritual ecological) system that was featured by the prevalence of scientism and waning of humanity. The other is to suggest that the restoration of the traditions of Natural Theology in China based on Shangshu and Yijing and Natural Theology in the West taught by Aristotle, Aquinas, and A.N. Whitehead, serve for the philosophical foundation for the coming of ecological civilization.

Keywords: Natural Theology; Spiritual Ecology; Comparative Philosophy

Heaven and Earth were born with me and Myriads of Things are one with me.

天地與我並生, 萬物與我為一。

-- “On Equality of Things,” Zhuangzi《莊子·齊物論》

Keep oneself upright and virtuous, utilize natural and human resources, and benefit people's livelihood; all should be done in accordance with the principle of harmony.

正德, 利用, 厚生, 唯和。

-- “Dayu Mo," Shangshu《尚書·大禹謨》

Men are the children of the Universe, with foolish enterprises and irrational hopes.

--A. N. Whitehead, Modes of Thought (1938/1966: 30) 


\section{Annals of Bioethics \& Clinical Applications}

\section{The Alarming News}

In the year 2019, the alarming news of the burndown of Amazon rainforest, the disappearance of Okjokull glacier in Iceland, the worsening of ocean pollutions and many others all indicate the increasing tendency of global warming, the critical moment of ecological collapse, and the dim future of human civilizations. Fire raging in the Amazon rainforest, the lung of the Earth, is said to be the consequence of US-China economic warfare the Brazilian farmers started fires in order to claim more land to cultivate soybeans sold to China as a replacement for US' soybeans. Numberless species, plants, insects, and animals were killed; their habitat was ruined and hardly recovered. Another strike on environmental protections that got less notice than the Amazon catastrophe was the loss of Okjokull or OK Glacier, one of 400 ancient glaciers shrouding the mountains of Iceland. The glacier lost its status in 2014 due to global warming which made it shrink too much into a puddle. It now turned to be the first Icelandic glacier to vanish forever and all other 400 glaciers will likely to follow its footstep. A memorial plaque recorded the cause of the death of the glacier "415ppm C02," the current ratio of greenhouse gases in Earth's atmosphere and almost the highest amount in our planet ever since humans evolved. Another dreadful scene is the ocean plastic pollution which jeopardizes all marine and island lives; plastic wastes and microplastics drifting around the world by sea waves contaminated oceans and caused irreversible damages. All this indicates we human beings are responsible for the present total collapse of the natural environment and doomed to take the severest consequence.

\section{Environmental Movements in the West of the Mid-20 th Century}

Just like A. N. Whitehead (1861-1947) once says in Science and the Modern World, Any physical object which by its influence deteriorates its environment, commits suicide [1], it is hard for us to understand why we human beings continue this suicidal way of life without necessary rectifications when the unavoidable consequence can be predicted. In fact, ever since the sixtieth of the $20^{\text {th }}$ century, waves of environmental movements in the West were already surging; the publication of Rachel Carson's Silent Spring in 1962 was generally regarded as the milestone of environmentalism [2]. It was followed by the blooming of environmental ethics and eco-theology, most notably Lynn White's paper, "The Historical Roots of Our Ecological Crisis" (1967), that not only acknowledged the seriousness of the ecological crisis posed to humankind, but also traced back its historical root to the JudeoChristian tradition of the West, and pushed the environmental issues to an ethical and religious level $[3,4]$. According to White, modern science and technology that was exclusively developed by the Occident and made their disastrous impact on ecology had gotten their origin and support from Christianity. Christianity, in White's view, being the most anthropocentric religion in the world, "not only established a dualism of man and nature but also insisted that it is God's will that man exploit nature for his proper ends [5]. Though White also appreciates Saint Francis of Assisi (1182-1226) preaching brotherhood between man and all beings as "a patron saint for ecologists" and representative of spiritual egalitarianism, that did not change his general impressions on Christianity being guilty of anthropocentrism [6].

In response to or contrast to White's taking Christianity's accountability of the traditional Western view of the privilege of man domination over nature, a number of Christian theologians, such as Rene Dubos, Joseph Sittler, Richard A. Baer, Paul Santmire, and many others, have attempted to argue the Christian perspective of environmental ethics and the stewardship doctrine of eco-theology. Admittedly God trusted nature, his creation, to human hands, which does not mean that humans are entitled to abuse and spoil nature. It is rather humans' obligation to God to safeguard and conserve nature as a faithful steward [7]. As Paul Santmire suggests, Christian anthropocentrism should not be interpreted as a warrant for human's dictatorship over nature, but rather be understood as a trustee for man's stewardship of nature [8]. Agreeing with Santmire, Rene Dubos was of the opinion that St. Benedict of Nursia (480-547) took the place of St. Francis as the patron of ecology, for he thought that St. Benedict and his followers had not taken nature as nature as St. Francis did, but diligently transformed brute nature and messy wilderness into suitable living environments. Therefore Dubos saw the Benedictine best exemplars of Christian stewardship who displayed an "ethical attitude" toward their environment [9].

\section{Process Philosophy and Eco-Theology}

Parallel to or even earlier than the above-mentioned development, historian of environmental ethics, Roderick Nash, noticed that the "process" philosophy of Whitehead had been the source of some modern American theologians, such as Charles Hartshorne (1897-2000), 


\section{Annals of Bioethics \& Clinical Applications}

Daniel Day Williams, Conrad Bonifazi, John B. Cobb, Jr., and so on, who were interested in investigating the ethical consequences of human expansion to nature. Among them, he singled out John Cobb as the one who had made significant contributions to environmental theology [10]. It was also said that John Cobb's is it too Late? A Theology of Ecology was the first book published by a philosopher on environmental ethics [11]. However, before the publication of that book, Cobb already wrote several articles on the subject, including "Ecological Disaster and the Church," [12] "The Population Explosion and the Rights of the Subhuman World," [13] and "Christian Theism and the Ecological Crisis" [14]. Based on Whitehead's ideas of organism and process, as Nash says, Cobb has taken "everything from humans through the various forms of non-human life, right down to cells, atoms, and subatomic particles" to have a purpose, a capability of being fulfilled or being denied that opportunity. So as God desires fulfillment as part of the requirement for divine perfection, the "subhuman world" is thereby invested with "rights" that humans, as the most intelligent form of life on earth, should respect [15]. Cobb also suggested humans extend Christian love to the subhuman world, not because they have instrumental use for us, but because they have intrinsic value for themselves. Nash also saw that Cobb had proposed a "new Christianity" to "substitute a vision of a health biotic pyramid" with man as the "apex of nature" that maintains the enlightened Christian anthropocentrism by no means standing for human domination over nature, but rather warranting human responsibility and love for nature. In this way, Nash remarks, Cobb called for a "religion of life," 'and his willingness to extend his moral vision down to "cells" and up to "biospheres" and "ecosystems," marks a milestone in the greening of both Christian and naturalrights liberalism'. Cobb's consciousness of Christians' responsibility for the environment and nature was echoed by many Christian theologians since the 1970s, and in the past decades, he has extended this responsibility specifically to China with the joined efforts made by Wang Zhihe and Fan Meijiun, the co-directors of China Project, Center for Process Studies [16].

\section{Modern Anthropocentric Mentality}

In this sketchy background of the rising of ecological theology or spiritual ecology, it is not hard to find that the Westerners' concern with the environmental issues was generally passive, though a conscientious, response to the disastrous consequences caused by their abusive use of science and technology and their lack of respect for
Mother Nature. Since Christianity has been the most influential religion of the West in the past two millennia and has provided sufficient biblical evidence for supporting the accusations of anthropocentrism [17], it is called to account for brewing the modern mentality behind all these. Admittedly there are as many "positive Christians" who respect nature to be equal to human beings, as there are "negative Christians" who take nature for granted to serve human need without paying any due respect. An alarming example for the latter was given in the recent American Republican primary campaign 2012 that Rick Santorum in his campaign for the Republican presidential candidate accused Obama of putting his environmental agenda in a "phony theology." The "phony theology," as Santorum described, teaches "man is here to serve the Earth," and it is a worldview that "elevates the earth above man and says we can't take those resources because it's going to harm the Earth, it's just all an attempt to centralize power and give more power to the government"[18]. According to Santorum, all this shows Obama's sponsorship of a different theology not based on the Bible but some secular values. Nonetheless, whoever has a heart for nature will agree on Obama's message of self-restraint on the part of humans? So if we do not admit nature to be our equal, we must at least understand being a member of nature to harm nature can never be good for humans in the long run [19].

However, to see it from a different perspective, owing to the same origin of Judaism as Islam, Christianity did not portray a completely different picture of the HumanNature relationship from that of Islam. So if the anthropocentric religious beliefs should take the blame for current environmental crises, Islam, at least, must not be spared either; which is in fact not the case. So to check the factual reality the only "suspect" guilty of causing the present human predicament of failing to conserve nature and to maintain sustainable survival for all beings on the earth is but "Modernization" for the West and "Westernization" for the rest of the world, including China. Nevertheless, Santorum's case indicates that the Biblical impact on the West does, in many ways, enhance the modern anthropocentric mentality.

Admittedly, the Occidental modernization impelled by the industrial revolution together with the capitalist economy and democratic movements brought about the total change of the traditional ways of living. By this drastic change, the Western people enjoyed so much knowledge, fortune, freedom, and power which made every non-Western people aspire to have exactly the 


\section{Annals of Bioethics \& Clinical Applications}

same. Just like Max Weber observed, the modern Western civilization of industrial capitalism based on science and technology displays a direction of the universal history of the world that prevailed on all non-Occidental traditions [20]. However, the joint-development of modernization and westernization all over the world not only resulted in the ecological crisis of the earth but also promoted the perverted mentality of fetishism, consumerism, and ethical nihilism conducing to the breakdown of the spiritual ecology of human society.

\section{Environmental Breakdown: Non-Religious Factors}

Ever since the emergence of human beings and human civilizations, nature had long been submitted to manmade changes for several thousands of years. However, it was not until the tremendous advancement of science and technology, that brought humans all the powers to change the natural world have they posed a real threat to nature. With the equipment of science and technology humans exploited all kinds of natural resources and thereby polluted the air, soil, rivers, lakes, underground waters, wetlands, forests, and oceans, wherever they could reach. By burning fossil fuels, emitting greenhouse gases, destroying rain forests and the ozone layer, and so on, they pushed the biosphere and ecosystem of the earth to the brink of collapse which has been explicitly shown in the form of Climate Change. It should be recognized that never before has there been any natural species on the earth as "homo sapiens" that might be able to decide its own destiny and the destiny of its living environment. At the beginning of the 21st century, we find ourselves facing a critical moment of either resolving the tension between humans and nature or perishing together with environmental destructions. In this context, only humans should take responsibility and the consequences, not "God" or any religious beliefs.

\section{Ethical and Religious Concern for Nature}

It is not to say religion bears no significance on the environmental issue, as most of the scientists and popular opinions supposed, the problem being caused by science and technology in which the solution must be found. Contrariwise, since the issue in one connection has to do with "the abusive use" of science and technology, it is deeply involved with an overall Human-Nature relationship and all the related social, political, and economic problems, not science and technology per se, which is in fact an issue of human concern in its broadest scale, and thereby something of ethical and religious concern is at its core. The environmental issue cannot be solved "technically," because it is more than a "technical" problem; it demands a full consideration and readjustment of Human-Nature relationship which is presupposed by the ideas of the universe as an interrelated, organic whole and human being as its integral part. Behind all this, there must be a religious bearing concerning what we believe to be the ultimate, universal, and supreme reality that grounds all beings and unites all aspects of our experience, in a word, that elicits in our mind a sense of wholeness and universal consciousness.

In addition, the issue in another connection has to do with a "lack of respect for nature," and the modern mentalities of extravagance, immoderation, and arrogance make nature as a human possession that can be taken advantage of so long as it is within their power. Nature lost its position of parenthood to humans and was taken only of instrumental value. The amendment of the distorted psychology might heavily rely on some religious sentiments that can nourish our respect for nature and help us to see nature as of intrinsic value.

What we will do is much determined by what we believe. What does nature mean to us? What is man's place in nature? What is the ultimate reality of which man and nature are its interrelated parts? In connection with these questions, two opposite views have been widely held in the West. One is the Christian view of monotheistic creationism, which teaches that nature is the creation of God; God has created man after his own image and granted him the power to dominate nature and all beings. The other is the Darwinian view of scientific evolutionism that asserts human beings are just one of the natural species evolved by following the natural laws; no intrinsic value or purpose can be found in the brute fact of nature except the blind impetus of self-preservation and the struggle for survivals. The first view based on religious faith believes in one supernatural, personal God and revealed Scripture that has been challenged continuously by non-believers of all kinds, and questioned by rational discourses and scientific knowledge. The second view as the climax development of scientific materialism leaves little room for spiritual values and religious concerns which are necessary to revamp the broken relationship between man and nature. Both views take nature as consisting of "things" without intrinsic value; either as "things" produced by the miraculous hands of God or as "things" bound to the inexorable law of causal 


\section{Annals of Bioethics \& Clinical Applications}

mechanism. Neither of them fit our present purpose to restore the peaceful and harmonious way of living in nature. There is a need for us to seek other alternatives. It seems that the traditions of natural or philosophical theology East and West, despite their differences, generally agreeing on the divinity of nature and man as its organic part may be worth our attention.

\section{Western Natural Theology}

The conception of "natural theology" [21-25], according to Werner Jaeger, the idea of theologia naturalis first appeared in the De civitate Dei of St. Augustine and is in contrast to mythical theology and political theology based on Varro's division. It was later received by Thomas Aquinas and transformed into the opposite idea of "revealed religion." The significance of natural theology was controversial, and the very concept has been seriously challenged or rejected by major schools in both philosophy and theology. Historically it was denounced by the Hume's arguments against anthropomorphism, the doctrines of natural law (cosmological arguments), and divine design (design arguments) in it. Following Hume, modern logical positivists, as John Hutchison said, "consigned the statement of natural theology to the limbo of nonsense," according to the verification principle. From the theological side, the biblical theologians asserted that man approaches God only by faith, and there is no significant role for reason to play in founding religious belief. However, the present paper argue that natural theology is an inevitable trend for the future development of Western theology that compromises reason with faith, nature with divinity, philosophy with religion. Also, ancient Chinese should be regarded as the earliest people in the world recorded who anticipated this inevitable trend.

"Natural theology" appeared in Western literature as in opposition to "revealed theology" (i.e., supernatural theology) having been closely associated with Thomas Aquinas (1224-1274) who endeavored to set the foundation of religious faith on human reason and morality and argued for the existence of God by philosophical demonstrations derived from Aristotle's metaphysics. Holding the Christian faith in the omnipotent, omniscient, eternal, perfect, infinite, absolute being of God and revealed Scripture, Aquinas also sees the importance of philosophy, especially that of Aristotle, a Pre-Christ pagan, who argues for the existence of God as the Prime Mover, Unmoved Mover, First Cause, Final Cause, Pure Form, Self-dependent Actuality, etc., to be the source of rational theology. As Aquinas remarked, "Faith professes and reason investigates" and "Now just as Sacred Teaching is founded on the light of faith, so philosophy is founded on the natural light of reason" [26], he admitted the Christian faith in divine God beyond the ken of reason, but reason can be the preambles of faith as the two must be united in one truth. So Aquinas resorts to natural law manifestly displayed by the orderly uniform movements of natural objects for the unison of God to man. In his view, human good or evil belongs to the precepts of the law of nature based on which human beings decide what is to be done or avoided. Human law or moral law is derived from natural law, and the content of the former conforms to that of the latter. In this way, natural theology was primarily of ethical nature that appeals to human reason and morality as the foundation of religious belief. Aquinas was the first theologian who gave natural law the central role in moral theory and made it the basis of the principles of practical rationality [27].

The opposition of "natural theology" to "revealed theology" was enlarged after Aquinas. Following this train of thought Rene Descartes (1596-1650) wrote, "I have always considered that the two questions respecting God and the Soul were the chiefs of those that ought to be demonstrated by philosophical rather than theological argument it certainly does not seem possible to persuade infidels of any religion, indeed, we may almost say, of any moral virtue, unless, to begin with, we prove these two facts by means of natural reason" [28]. In comparison to Aquinas, Descartes' words state a stronger case for reason than for faith, and in his view, two important issues of religion, the existence of God and the immortality of the soul, should find their proofs in reason, not in faith. Religious belief should not contradict human reason and can only be confirmed by reason. At the same time, there were a number of theologians who tended to identify God with nature. Most notably was Baruch Spinoza (16321677) who proposed the type of natural theology that was termed "pantheism." To see "Natura naturans" (nature naturing) be one with "Natura naturata" (nature natured), by the famous phrases adopting from Nicolaus Cusanus and Girodano Bruno (1548-1600) to describe God and nature respectively, Spinoza conceived God as one infinite substance identical with nature and God within nature; the self-caused Creator is one with the caused Creature [29,30]. In this way, Spinoza transformed the transcendent Judeo-Christian God into an immanent natural God and furthered the development of natural theology in a fundamental way. Following Spinoza's step, 


\section{Annals of Bioethics \& Clinical Applications}

Gottfried W. Leibniz (1646-1716), the first European philosopher who introduced ancient Chinese thought to the West and discerned there was natural theology in it [31], argued for the conformity of faith with reason and confirmed that the former will not contradict the latter, as he wrote, "I assume that the two truths cannot contradict each other; that the object of faith is the truth God has revealed in an extraordinary way; and that reason is the linking together of truths, but especially of those whereto the human mind can attain naturally without being aided by the light of faith" [32]. Though Leibniz admitted that "God can exempt creatures from the laws he has prescribed for them, and produced in them that which their nature does not bear by performing a miracle" [33], he carefully ascribed the performance to angels, the agencies of God, and assimilated it to human art so as to avoid the charge of violating the natural laws [34]. Again, Leibniz distinguished a difference between "what is above reason" and "what is against reason," and maintained that the Mysteries in Christian faith belong to the realm of former as something that is beyond human comprehension but not to the latter as something opposed to reason [35]. In one way or another, Leibniz had tried his best to hold a Christian faith and at the same time to avoid allowing it to conflict with reason.

While later philosophers began to lay more and more emphases on the contrasts between revealed theology and natural theology, religion and philosophy, faith and reason, supernatural and natural, and so on, and found them incompatible with each other. In their view, revealed theology appeals to divine revelation for the religious belief in one supernatural God, the Scriptures, and miracles violating the laws of nature, whereas natural theology sees God as the giver of natural law, who will never violate the very law ordained by God Himself, which is in fact the very exemplification of God. The former is convinced that there is supernatural power possessed by Almighty God who can intervene in the operations of the natural laws at His will and introduce miracles to demonstrate the eminent existence of God. The latter maintains that no such thing is necessary since there is no God besides the natural laws. Jean-Jacques Rousseau expressed this position most vividly in "The Creed of a Savoyard Priest," when he wrote, "In my exposition you find nothing but natural religion; strange that we should need more. Show me what you can add to the duties of the natural law. The grandest ideas of the Divine nature come to us from reason only listen to the inner voice. What more can man tell us? There revelation do but degrade God, by investing him with passions like our own" [36]. So he urged people not to confound the ritualism and formalism of religion with the religious sentiments of natural piety, true spirit, moral conscience and natural reason since the service God requires is the sincerity of the heart, not the form of worship [37].

Rousseau's rebellious spirit against formal religion and appealing to religious sentiments were echoed by David Hume (1711-1776) and succeeded by Immanuel Kant (1724-1804), and both of them resolved to inveigh against natural theology based on pure reason [38,39]. Hume with his skepticism accused natural theology of committing the error of anthropomorphism arising from human nature that produces arguments for the existence of God from natural laws and from intelligent design without any evidence of empirical support; whereas Kant with his critical philosophy denied pure reason to the capacity of knowing the nature and existence of God and thereby rejected the natural theology of traditional rationalism. Natural theology or religion was then led by Hume to the direction of radical empiricism or naturalistic skepticism that sought the explanation of religious phenomena from some anthropological, psychological, and sociological sources, and by Kant to the direction of moral theology that makes moral laws take the place of natural laws in theology. It was then carried on by the English Deists since the 18th century and the German Idealists since the 19th century and became blurred and waned in the trends of positivism and irrationalism.

\section{Process Theology and Panentheism}

The tradition of natural theology was revived by the modern process philosophers, especially by Whitehead in the early 20th century. Based on Whitehead's process philosophy Hartshorne and John Cobb and many others initiated a new theological movement; the so-called process theology flourished in the later-half of the 20th century in the United States. Previously a logician and mathematician that leaned to the agnostic position in religion [40], Whitehead turned out to be a philosophical theist after the publication of his Science and the Modern World (1925) and proceeded to develop in his Process and Reality (1929) a type of natural theology that was later termed "panentheism" by Hartshorne. In the Science and the Modern World Whitehead took on the Aristotelian conception of God as a Prime Mover and argued for a transformation of the ultimate presupposition of his philosophical theology from the First Cause that is supported by the physics of material 


\section{Annals of Bioethics \& Clinical Applications}

substances to the Principle of Limitation and of Concretion that is presupposed by the concrete existence of actual temporalities (actual occasions), namely the process. For Whitehead, nature is composed of units of experience, not inert matter or material substances. God as the Principle of Limitation provides them with the ultimate metaphysical situation that is the ground for the limitation of antecedent causes and the limitation of value standards for the concretion and realization of the becoming units [41]. Thus for Whitehead, God is the ultimate limitation, the ground for concrete actuality, and no further reason can be given for God's nature and existence. Yet God becomes known to us not only by metaphysical reason; He must be sought in our religious experience, as Whitehead remarks, "In respect to the interpretation of these experiences, mankind has differed profoundly. He has been named respectively, Jehovah, Allah, Brahma, and Father in Heaven, Order of Heaven, First Cause, Supreme Being, and Chance. Each name corresponds to a system of thought derived from the experiences of those who have used it" [42]. Thus Whitehead was quite aware of the difference between philosophical theology and formal religion: the metaphysical ultimate inspiring in us similar religious experience and sentiments is the core of the former, whereas various names given by different spiritual traditions are the particularizations of it by the latter.

By replacing the concept of substance in the Aristotelian metaphysics with the concept of process Whitehead at the same time introduces a relative and limited conception of God in place of the traditionally absolute and infinite conception of God. As Whitehead observed, the combination of Aristotelian metaphysics and Christian theology yielded "the doctrine of an aboriginal, eminently real, transcendent creator, at whose fiat the world came into being, and whose imposed will it must obey," and led to the tragedies that occurred in the Christian and Muslim histories [43]. Religious exclusiveness, the idea of a terrifying, supernatural, personal God and of a transcendent creator that rules over his creation, and the eternality of Supreme Being shadowed the world, are the defects that Whitehead has detected in the traditional monotheism. So Whitehead set up to construe the ideas of God and the world and their mutual relations in terms of a new type of natural theology-- panentheism. According to Whitehead, God is of a dipolar nature: by his primordial nature God provides the world with the ground of infinite potentiality, possibility, and ideality and by his consequent nature God is not before all creation, but with all creation. The former is free, infinite, eternal, actually deficient, and unconscious, whereas the latter is determined, everlasting, transient, fully actual, and conscious. In this case, the world is not a creation of God, but a self-created process that has the same characteristic creativity as that of God. The opposition of God and the world turns to be some contrasts mutually exchangeable, as Whitehead says, it is true to say God is permanent and the World fluent as that the World is permanent and God is fluent; the World is immanent in God, as that God is immanent in the World; God transcends the World, as the World transcends God; God creates the World, as that World creates God and so forth [44]. Thus in Whitehead, there is a complementary and dialectical logic in our understanding of God. The conception of God should not be identified with "the Absolute" only, nor have the onesided attributes of infinity, immutability, eternity, and necessity. God is to have both attributes of "the absolute and the relative," "the finite and the infinite," "the eternal and the temporal," "the necessary and the contingent." For him, the relation of God to the world is no longer one way the world as a creature is entirely dependent on God, but God as Creator is independent of the world, but double way God is also relatively dependent on the world in an unceasing creative process.

Whitehead's process philosophy and his panentheistic idea of God exerted great influences on American process theologians, Hartshorne, Cobb and David R. Griffin who generally agreed on this relative and antithetic concept of God that may exempt traditional theistic God from the responsibility for whatever happened in the world, as He is no longer the origin of all evil or all good. Both God and the creatures are actual entities, i.e., processes of becoming, equal in their character of creativity and therefore responsible for whatever they have done. So by following Whitehead, Hartshorne has proclaimed a thesis of "Surrelativism" or "Panentheism" which holds the "relative" or changeable to include within itself and in value exceeding the non-relative, immutable, independent, or "absolute," as "the concrete includes and exceeds the abstract" $[45,46]$. Hartshorne maintains that surrelativism holds both the personality of deity and the cosmic totality of deity, and it suggests the total actual state of deity-now, as surrelative to the present universe, has nothing outside itself. Whereas the term "panentheism" refers to the view that deity is in some real aspect distinguishable from the independent of any and all relative items, and yet, taken an actual whole, includes all relative items. Cobb and Griffin advanced Whitehead and Hartshorne's idea of God to a Christian natural 


\section{Annals of Bioethics \& Clinical Applications}

theology and thereby restored the current meaning of religious God which had been dismissed by modern positivism, atheism, materialism, scientism, and nihilism [47-49].

Process theologians construe that whatever exists just like God Himself is self-caused and self-created, and therefore must take its own self-responsibility and accomplish its own course in which God only as the metaphysical ground provides it with reason and hope. It seems that natural theology developed in the West to the stage of process theology has made a significant step in transforming the classical theistic conception of God as the omniscient and omnipotent Creator to the philosophical-theological conception of God as a synthetic becoming that integrates all contrasts in the world. By this way, process theology may be regarded as a close ally to ancient Chinese thought that had been identified by Leibniz to be abundant of the elements of natural theology.

\section{Chinese Natural Theology}

As Leibniz, together with the Jesuits of the 16th century, found in the ancient Chinese text Shangshu (The Book of Ancient History), the word "tian day" or "Heaven day" implies both heaven in the sense of physical nature and a personal God, which indicates an original form of natural religion and moral theology and bears a great significance to any rationalized and humanized religion. There are also the terms "tianzhi" (heavenly ranking, natural order) and "tianxiu" (heavenly precepts) in the Shangshu referring to both natural law and moral law, while the combination of the two has always been the primary feature of natural theology in the West.

Besides the Shangshu, Leibniz also discerned there is another antique source of Chinese natural theology, namely, the Book of Changes or Yijing. As one of the inventors of infinitesimal calculus, Leibniz proposed that the universe was generated out of pure being (God), or unity (1) and nothingness (0), and thereby modeled by a binary arithmetic system. He then learned from Bouvet, a French Missionary in China, that there were 64 hexagrams made up by unbroken (yang) and broken (yin) lines in the Book of Changes (Ye Kim) handed down by ancient Chinese sage-king Fuxi (Fohi) to simulate the process of cosmic creation. If one takes the unbroken line as number 1 and the broken line as the number 0 as Leibniz suggested, one will see that the 64 hexagrams represent exactly a binary arithmetic [50]. Also under the

Yih-hsien Yu. Seeking Philosophical Foundations for Ecological Civilization: Natural Theology East and West. Ann Bioethics Clin App 2019, 2(1): 000111. influence of the popular School of Neo-Confucianism (Sung-Ming Lixue), Leibniz understood there was the idea of God in the Chinese concept of Li (the Principle) or Tai-ji (the Ultimate), as he wrote, "I believe that this agrees with our way of speaking, since we speak of God as being a sphere or a circle whose center is everywhere and whose circumference is nowhere. They call it the Nature of things, which I believe corresponds to our saying that God is the Natura Naturante (the creative power of nature). We say nature is wise; that she does all for an end and nothing in vain. The Chinese also attribute to it truth and goodness as we attribute it to Being in our metaphysics. But apparently for the Chinese, just as the Li is being par excellence so it also possesses Truth and Goodness par excellence [51]. Obviously Leibniz had no idea that "the $\mathrm{Li}^{\prime}$ he referred to had been derived from the Dao of the Yijing by the neo-Confucians and the concept of Taiji (the Great Ultimate) also first appeared in the Yijing. As it is said in the Xizi Zhuan, "Yi (The Change, Creativity) possesses the Taiji (the Great Ultimate), from which Yin (Moon, Earth) and Yang (Sun, Heaven), the so-called "Two Models," were generated. The "Two Models" generate "Four Phenomena," Spring, Summer, Autumn, and Winter from which "Eight Hexagrams," which are Ch'ien, K'un, Ch'en, Ken, K'an, Li, Hsun, and Tui, representing heaven, earth, sounder, mountain, water, fire, wind, and lake respectively, were generated. The "Eight Hexagrams" in turn determine the Auspicious and the Ominous from which the Great Enterprises of humankind were produced." (《易·繫辭傳》：「是故易有太極, 是生兩 儀。兩儀生四象, 四象生八卦。八卦定吉凶, 吉凶生大 業。」) As for the concept of Dao, a synonym of Yi is constantly referred in the Xizi Zhuan, as it says, "What is metaphysical, supersensible, is Principle or Dao; whereas what is concrete, sensible, is Material, Artifact, or Qi." ( $「$ 是故形而上者謂之道。形而下者謂之器。」) Again, it says, "What is called Dao functions incessantly with the orderly alternations of Yin (Moon, the Feminine Principle) and Yang (Sun, the Masculine Principle). What succeeds to it is the Good and what fulfills it is the Essence and Nature of Things. It manifests itself in the rational sentiment of humanity but keeps its function concealed. Without sharing any worry with the Sage-Kings, it inspires myriads of things with life. Its richness of virtue, its grandeur of enterprise, is of the most sublime. To acquire great fortune is called Great Enterprise. To reform oneself daily is called High Virtue. The incessant generation of Nature is called Creativity. The unpredictability of the alternations of yin and yang is called Shen (divinity, deity)." (「一陰一陽之謂道, 繼之者善也, 成之者性也 。仁者見之謂之仁, 知者見之謂之知。百姓日用而不知 


\section{Annals of Bioethics \& Clinical Applications}

\begin{abstract}
故君子之道鮮以聞, 顯諸仁, 藏諸用。鼓萬物而不與 聖人同憂, 盛德大業至矣哉! 富有之謂大業, 日新之謂 盛德。生生之謂易。」) Here the trace of the elements of natural theology can be easily found in these paragraphs: Moral Law and Natural Law were identified as one by the author of Xizi Zhuan, yet no specific god even as that in the Shangshu has been indicated [52].
\end{abstract}

It should be noted that in the paragraph abovementioned where the term "Taiji" has its first and only appearance, there is nothing cryptic but only an idea of natural order represented by two symbols of yin and yang with mathematical necessity. However, when the concept of Taiji came to the Sung-Ming Li School, it was severely contaminated by the doctrine of Yin-Yang and Five Agents which was developed by the Yin-Yang School of the Warring Period in the Pre-Qin Dynasty and later advocated the Religious Daoism and, in this way, they made the rational cosmology in the Yi-Jing take on a defective form of cosmogony. Nonetheless, this did not reduce the value of Leibniz's finding of the metaphysical and theological bearings of these concepts as a parallel to God.

Undeniably, the traditions of natural theology in China and the West have essential differences. The Supreme Being or Shen (or Dao, or Taiji) in Chinese natural theology is generally a natural deity without any specific name or revealed story, and has never inspired any institution of formal religion in China; though it might have been usurped by religious folk to justify their beliefs in deified heroes and seek their deification. The idea of deity in China is closer to that of the "theos" in Greek theology, divine, unpredictable and acting miraculously, and to that of the "First Cause" in Aristotelian metaphysics, initiating the creation of the universe, than to the personal God of Christianity. It is curious, but truthful to say that Chinese natural theology sponsored both the theistic and the non-theistic types of worship as Hartshorne once distinguished, when he wrote, "there are two possible theories of worship, the theistic one and the non-theistic. According to the former, the conscious wholeness of the individual is correlative to an inclusive wholeness in the world of which the individual is aware, and this wholeness is deity. According to the non-theistic view, either there is no inclusive wholeness, or if there is one, it is not what religions have meant by deity. Perhaps it is just The Unknown, or Nature as a Great Mystery, not to be thought of as conscious, or as an individual in principle superior to all others. Perhaps it is even Humanity. Or (more reasonably) it is all sentient creatures [53]. For the Chinese, so long as the deity is without a name, a number, or substantial existence, just as the mysterious function of nature, it could be the object worshipped and prayed to, as Confucius once exclaimed, "Condemned by Heaven, no place left to pray!" So in the Chinese view, the theistic and the non-theistic worships are not incompatible, but complementary; the Chinese honestly acknowledge to both our religious feeling of divinity and our ignorance of the mystery of the Ultimate. Our religious feeling gives rise in our heart the belief in deities, whereas our ignorance deters us from making any definite claims on the nature and substantial existence of the deities. It is a pity that Hartshorne has made a blunt comment, as he himself acknowledged, on the non-theistic worship as an indication of ignorance of lower animals [54]. Should he have recalled what Whitehead once suggested regarding the existence of God as the inexplicable "ultimate irrationality," he might have avoided committing such a blunder [55].

\section{Final Words}

The history of human struggle for civilization out of a harsh natural environment has unavoidably defined the conflicting relations between humans and nature; we are the only natural species that has created a world of our own out of nature. The more human civilization developed, the less we become conscious of ourselves being a member of nature, and eventually totally lost our respect and care for nature. The traditions of natural theology both in China and the West show that there has been a time that nature and humanity were in unison in terms of natural law, natural reason, and natural piety. The time in the West can be traced back to ancient Greece about two thousand and five hundred years ago and in China about three thousand years ago as recorded by the Six Classics. The organic and harmonious relations between nature and humanity has long been the subject of eulogy by the prominent schools of Confucianism and Daoism in ancient China, and they never tired to urge people to "follow the way of Nature," "revere Heaven and Earth," "be one with nature," "be temperate and selfrestrained," "be beneficent and merciful," "be frugal and sparing," and so forth. On the other hand, the traditional Western natural theology has been a concern of the ultimate and reconciliations of faith and reason, which has many significant religious bearings. It must be acknowledged that religious faith is essentially private, personal, even mystical, and to some extent, incommunicable. There are always believers and nonbelievers with respect to any particular religion. By 
appealing to reason and rational arguments, natural theology in the West has done its best to pull the two extremes as close to each other as possible. It seems that the traditions of natural theology both in China and the West have enshrined the most precious elements of humanity: reason, conscience, reverence, religious sentiments and sense of wholeness which are indispensable to a healthy spiritual ecology and therefore the foundation of any ecological civilization. Bearing this in mind, we may argue that the breakdown of the bioecological system conducive to the increasing environmental crises threatening the sustainable existence of both nature and mankind has been underlain by the breakdown of the psycho/spiritual ecological system that was featured by the prevalence of scientism and waning of humanity. So we might expect the restoration of the traditions of natural theology both in China and the West can serve as a help for us to cope with the devastating situation.

\section{References}

1. Whitehead AN (1925) Science and the Modern World. Open Library 28 ${ }^{\text {th }}$ (Edn.) pp: 112.

2. Carson R, Silent Spring (Boston: Houghton Mifflin, 1962); John McCormick, The Global Environmental Movement (New York: John Wiley \& Sons, 1995).

3. White L (1967) The Historical Roots of Our Ecological Crisis. Science 155(3767): 1203-1207.

4. Gotflieb RS (1996) This Sacred Earth Religion, Nature, Environment. Routledge, New York and London, pp: 185-193.

5. Gotflieb RS (1996) This Sacred Earth Religion, Nature, Environment. Routledge, New York and London, pp: 189.

6. Nash $\mathrm{R}$ The Greening of Religion. In: Gotflieb RS (2003) This Sacred Earth Religion, Nature, Environment, $2^{\text {nd }}($ Edn.), pp: 198-210.

7. Gotflieb RS (2003) This Sacred Earth Religion, Nature, Environment. $2^{\text {nd }}(E d n)$, pp: 203-206.

8. Gotflieb RS (2003) This Sacred Earth Religion, Nature, Environment, $2^{\text {nd }}($ Edn.), pp: 208-209.

9. Gotflieb RS (2003) This Sacred Earth Religion, Nature, Environment, 2nd (Edn.), pp: 201-202.

Yih-hsien Yu. Seeking Philosophical Foundations for Ecological Civilization: Natural Theology East and West. Ann Bioethics Clin App 2019, 2(1): 000111.
10. Gotflieb RS (2003) This Sacred Earth Religion, Nature, Environment. $2^{\text {nd }}($ Edn.), pp: 210.

11. Cobb JB (1972) Is It Too Late? A Theology of Ecology. Beverly Hills, Ca: Bruce.

12. Cobb JB (1970) Ecological Disaster and the Church. Christian Century 87: 1185-1187.

13. Cobb JB (1970) The Population Explosion and the Rights of the Subhuman World. IDOC, pp: 41-62.

14. Cobb JB (1971) Christian Theism and the Ecological Crisis. Religious Education 66(1): 23-30.

15. Nash R The Greening of Religion. In: Gotflieb RS, (Eds.), This Sacred Earth Religion, Nature, Environment, pp: 210.

16. Nash R The Greening of Religion. In: Gotflieb RS, (Eds.), This Sacred Earth Religion, Nature, Environment, pp: 211.

17. (1979) Peter Singer, Practical Ethics. Cambridge University Press, New York, pp: 265-269.

18. (2012) It was reported that Santorum made these remarks when he appeared on CBS "Face the Nation,". He had already made the accusation at a number of his campaign speeches.

19. As what has happened, Obama went to Paris to attend the 2015 United Nations Climate Change Conference in Paris and made a non-coercive agreement on reducing carbon emissions, which was blatantly denied by his successor President Trump. Trump disbelieves the emission of carbon dioxide as the cause of global warming and climate change, and he not only withdrew the Paris Climate Accord in 2017 but also skipped over the G7 climate meeting in 2019.

20. Weber M (1978) The Origins of Industrial Capitalism in Europe. In: Runciman WG, (Eds.), Weber Selection in Translation, pp: 331-340.

21. Andrews ST (1936) The Theology of the Early Greek Philosophers. The Gifford Lectures, pp: 1-3.

22. Hutchison J (1958) The Uses of Natural Theology an Essay in Redefinition. The Journal of Philosophy 55(22): 936-944. 


\section{Annals of Bioethics \& Clinical Applications}

23. Plantinga A (1991) The Prospects for Natural Theology. Philosophical Perspectives 5: 287-315.

24. Matthews GB (1964) Theology and Natural Theology. The Journal of Philosophy 61(3): 99-108.

25. Smith JE (1958) The Present Status of Natural Theology. The Journal of Philosophy 55(22): 925-936.

26. Aquinas T (1946) Super Boetium de Trinitate, Q. III, a. 1, selection from St. Thomas Aquinas, translated by Rose E. Brennan, S.H.N, pp: 35-40.

27. Lewis E (1940) Natural Law and Expediency in Medieval Political Theory. Ethics 50(2): 144-163.

28. Descartes R (1970) Philosophical Works. In: Haldane ES, Ross GRT, (Eds.), Cambridge University Press 1: 133.

29. Wilhelm Windelband (1971) A History of Philosophy II Renaissance-Enlightenment-Modern. In: James HT, (Eds.), Rainbow-Bridge Book, Taipei, pp: 409.

30. Feldman S, de Spinoza B, Shirley S (1982) The Ethics and Selected Letters Hackett Publishing Co., Inc, Indiana, pp: 52.

31. Leibniz GW, Cook DJ, Rosemont H, von F (1994) Writings on China. Jr. translated, with an Introduction, Notes, and Commentaries, Illinois: Open Courtm, Chicago and La Salle.

32. Leibniz GW (1985) Theodicy. In: Translated by Austin Farrer, Huggard EM, Illinois, La Salle, pp: 73-106.

33. Leibniz GW (1985) Theodicy. In: Translated by Austin Farrer, Huggard EM, Illinois, La Salle, pp: 74.

34. Leibniz GW (1985) Theodicy. In: Translated by Austin Farrer, Huggard EM, Illinois, La Salle, pp: 75.

35. Leibniz GW (1985) Theodicy. In: Translated by Austin Farrer, Huggard EM, Illinois, La Salle, pp: 106.

36. Rousseau JJ (1955) Jean-Jacques Rousseau, Emile, or Education [1762], pp: 259.

37. Ibid.

38. (2007) Hume: Dialogues Concerning Natural Religion. IN: Coleman D, (Eds.), Cambridge University Press.

Yih-hsien Yu. Seeking Philosophical Foundations for Ecological Civilization: Natural Theology East and West. Ann Bioethics Clin App 2019, 2(1): 000111.
39. Kant I (1793) Religion within the Limits of Reason Alone, $1^{\text {st }}$ (Edn.).

40. Ford LS (2000) Transforming Process Theism. State University of New York Press 2: 380.

41. Whitehead AN (1925) Science and the Modern World. Academic, pp: 278.

42. Whitehead AN (1925) Science and the Modern World. Academic, pp: 179

43. Whitehead AN, Griffin DR, Sherburne DW (1978) Process and Reality, the Free Press, New York, pp: 342.

44. Whitehead AN, Griffin DR, Sherburne DW (1978) Process and Reality, the Free Press, New York, pp: 348.

45. Hartshorne C (1948) The Divine Relativity A Social Conception of God. Yale University Press, pp: 82-90.

46. Hartshorne C, Reese WL (1954) Philosophers Speak of God. The Journal of Religion 34(2): 1-16.

47. Hartshorne C (1968) A Natural Theology For Our Time 29(1): 130-133.

48. Cobb JB (1965) A Christian Natural Theology Based on the Thought of Alfred North Whitehead. Religion Online.

49. Griffin DR (2014) Panentheism and Scientific Naturalism Rethinking Evil, Morality, Religious Experience, Religious Pluralism, and the Academic Study of Religion, pp: 310.

50. Rosenmont H, Cook DK (1977) Introduction. In: Leibniz GW, (Eds.), Discourse on the Natural Theology of the Chinese, Monographs of the Society for Asian and Comparative Philosophy, no. 4, The University Press of Hawaii, USA, pp: 73-133.

51. Rosenmont H, Cook DK (1977) Introduction. In: Leibniz GW, (Eds.), Discourse on the Natural Theology of the Chinese, Monographs of the Society for Asian and Comparative Philosophy, no. 4, The University Press of Hawaii, USA, pp: 82-83.

52. Fang TH (1980) Creativity in Man and Nature, Linking Publishing Co. Ltd, Taipei, pp: 37. 


\section{Annals of Bioethics \& Clinical Applications}

53. Hartshorne C (1968) A Natural Theology for Our Time. International Phenomenological Society 29(1): 130-133.

54. Hartshorne C (1968) A Natural Theology for Our Time. International Phenomenological Society 29(1): 6.
55. Whitehead AN (1925) Science and the Modern World. Open Library 28th (Edn.), pp: 178. 